\title{
Settlement Disputes on Land Right Between Factory and Farmers Through Agrarian Reforma
}

\author{
Rachmah Risandi *) \\ ${ }^{*}$ Master of Notarial Law, Faculty of Law, Universitas Islam Sultan Agung, email: \\ shinici_me@yahoo.com
}

\begin{abstract}
The specific object in this research is Land Rights Dispute Settlement between PT. Karyadeka Alam Lestari with Farmers in Trisobo Village, Boja District, Kendal Regency through Agrarian Reforma with the formulation of the problem: (1) Why is there a dispute over tenure over land rights between PT. Karyadeka Alam Lestari with Farmers in Trisobo Village, Boja District, Kendal Regency? (2) What is the settlement of land rights tenure disputes between PT. Karyadeka Alam Lestari with farmers from Trisobo Village, Kendal Regency by the Regional Office of the National Land Agency of Central Java Province, is in accordance with the National Land Law? (3) What are the obstacles faced by the Regional Office of the National Land Agency of Central Java Province in resolving land tenure disputes between PT. Karyadeka Alam Lestari with farmers from Trisobo Village, Kendal Regency? (4) What is the follow-up to the settlement of land rights tenure disputes between PT. Karyadeka Alam Lestari with farmers from Trisobo Village, Kendal Regency through Agrarian Reforma? This study uses an empirical juridical approach with explanatory analysis research specifications. Primary data of this study were obtained from interviews with Central Java Provincial Office, Kendal District Land Office, PT. Karyadeka Alam Lestari and the head of Trisobo village using the snowball sampling method. The data collection techniques used were library studies and field studies. The data analysis technique used descriptive qualitative. The results of the research are: (1) The occurrence of land rights tenure disputes between PT. Karyadeka Alam Lestari with Farmers in Trisobo Village, Boja District, Kendal Regency because of the social disparity between Trisobo Village farmers and PT. Karyadeka Alam Lestari. (2) Settlement of land rights tenure disputes between PT. Karyadeka Alam Lestari with farmers from Trisobo Village, Kendal Regency, by the Regional Office of the National Land Agency of Central Java Province, is in accordance with the National Land Law. (3) The obstacle faced by the mediator is in providing a correct legal understanding of land control to the disputing parties. (4) The follow-up action taken by the Regional Office of the National Land Agency of Central Java Province is to determine a portion of the land object of the dispute covering an area of $11.5 \mathrm{Ha}$ is state land released by PT. Karyadeka Alam Lestari to Trisobo village and used as land Reforma land objects which will be redistributed to 570 farmer families in Trisobo Village, Boja District, Kendal Regency through the Agrarian Reforma program.
\end{abstract}

Keywords: Dispute Resolution; Land; Rights; Agrarian Reforma.

\section{Introduction}

Development in the agricultural sector in addition to achieving and enlarging agricultural production is also to improve the standard of living of farmers. This is because farmers are one of the driving factors for national development. Farmers are those whose livelihood (main) is cultivating agricultural land. However, in reality, many cases of tenant farmers are not land owners, farmers are just cultivators who from generation to generation cultivate agricultural land to support their children and 
grandchildren. So that without realizing it by the community (farmers), it turns out that the cultivated land is in a protected forest area or belongs to another party, while the farmers are ingrained with the environment (the land they cultivate).

Looking at the foregoing, it is necessary to have land law regulations that can provide legal certainty regarding the rights and obligations that protect the rights of the community. ${ }^{1}$ To protect the rights of the people and become the basis of land law in the constitution, namely Article 27 paragraph (2), Article 28 and Article 33 of the 1945 Constitution of the Republic of Indonesia. In particular, Article 33 paragraph (3) of the Basic Law The Republic of Indonesia of 1945 provides the basis for the birth of the authority as regulated in Article 2 paragraph (2) of Act No. 5 of 1960 concerning Basic Agrarian Regulations, hereinafter abbreviated as UUPA, to government / state institutions responsible for land affairs. The authority referred to in this article is ${ }^{2}$ :

a. Regulate and administer the designation, use of supplies and maintenance of earth, water and space;

b. Determine and regulate the legal relationships between people and earth, water and space;

c. Determine and regulate legal relationships between people, and legal actions concerning earth, water and space.

In this context, the institution that is mandated to carry out the arrangement of relations as described above is very strategic. This institution plays a full role in the effort to realize justice and prosperity for the people, nation and State of Indonesia which is independent, united and sovereign. ${ }^{3}$. So that it can be in accordance with the 3 main objectives namely 4 :

a. Laying the foundations for the formulation of a national agrarian law which will be a tool to bring prosperity, happiness and justice to the State and the people, especially the peasants, in the framework of a just and prosperous society;

b. Laying the foundations for unity and simplicity in the land law;

c. Laying the basis for providing legal certainty regarding land rights for the people as a whole.

Based on Presidential Regulation of the Republic of Indonesia Number 17 of 2015 concerning the Ministry of Agrarian Affairs and Spatial Planning and Presidential Regulation of the Republic of Indonesia Number 20 of 2015 concerning the National Land Agency, governmental duties in the land sector are nationally, regionally and

\footnotetext{
1 Widyawati, \& Handoko, Widhi. (2018). The Notary Role / PPAT in Improving Legal Awareness Society to Perform Registration Rights to Land Based on Government Regulation No. 24 of 1997 on Land Registration. JURNAL AKTA: Vol. 5, No. 4, 975-980. Retrieved from http://jurnal.unissula.ac.id/index.php/akta/article/view/4127

${ }^{2}$ The National Land Agency of the Republic of Indonesia, Agrarian Reforma, Mandate Political, Constitutional and Legal in the Context of Creating "Land for Justice and People's Welfare", 20 May 2007, p. 5.

3 lbid, p. 6.

${ }^{4}$ Harsono, Boedi. (2008). Sejarah Pembentukan Undang-Undang Pokok Agraria, Isi dan Pelaksanaannya Jakarta: Djambat. p. 219
} 
sectorally carried out by the National Land Agency which has now changed its name to Ministry of Agrarian Affairs and Spatial Planning / National Land Agency, hereinafter abbreviated as the Ministry of ATR / BPN. Thus the Ministry of ATR / BPN of the Republic of Indonesia is a government agency as the exercise of the authority of Article 2 paragraph (2) of the UUPA and is also the implementer of Agrarian Reforma as mandated by TAP No. IX / MPR / 2001. ${ }^{5}$

The imperative to carry out Agrarian Reforma (Agarian Reform) has been stated in the MPR-RI Decree Number IX / MPR / 2001 concerning Agrarian Reforma and Natural Resource Management mandates the government, among others, to carry out the restructuring of control, ownership, use and utilization of land (Landreform) that is just. by paying attention to land ownership for the people, as well as resolving conflicts relating to natural resources that have arisen so far as well as anticipating potential conflicts in the future in order to ensure the implementation of law enforcement ${ }^{6}$. Furthermore, MPR-RI Decree Number 5 of 2003 concerning Assignment to the Leadership of the MPR-RI to submit suggestions on the Implementation of the MPR-RI Decision by the President, DPR, BPK, MA at the 2003 MPR-RI Annual Session, ordered the President and DPR to implement Agrarian Reforma, among other things, resolves various conflicts and problems in the agrarian sector in a proportional and fair manner, from legal issues to implementation in the field, compiling laws and regulations related to Agrarian Reforma, and facilitating provision of land access for small communities, especially farmers. ${ }^{7}$

The dispute between the farmers in Trisobo Village, Kendal Regency, Central Java Province and PT. Karyadeka Alam Lestari started in 2000 when PT. Karyadeka alam Lestari is the holder of plantation land with the status of Use Rights (HGU) covering an area of $151.3 \mathrm{Ha}$ which expires in 2002 where an extension of its Land Rights will be proposed. However, before the expiration of the rights in 2002, part of the land had been plundered by the community in 2000 with a land area of 67.9 hectares of the total land area owned by PT. Karyadeka Alam Lestari above. In fact, the community does not question the ownership of land use rights (HGU) by PT. Karyadeka Alam Lestari, but there were other parties who provoked the community, including the village head, to loot land for Business Use Rights (HGU) by PT. Karyadeka Alam Lestari on the grounds that it does not contribute to the surrounding community. By mediating this problem with various parties, this problem could be resolved in 2012 .

Based on the description on the background of the problem above, the authors formulate the problems in this study as follows: Why is there a dispute over tenure over land rights between PT. Karyadeka Alam Lestari with Farmers in Trisobo Village, Boja District, Kendal Regency?; Is the settlement of land rights tenure disputes

\footnotetext{
${ }^{5}$ Harjanto, Fery., \& Gunarto. (2018). Effects Of Creation Deed of Sale and Purchase of Land Which Does Not Match Procedure of Making Land Deeds. JURNAL AKTA: Vol. 5, No. 4, 857-864. Retrieved from http://jurnal.unissula.ac.id/index.php/akta/article/view/3718

${ }^{6}$ National Land Agency of the Republic of Indonesia, loc. cit.

${ }^{7}$ Alam, Bahrul., \& Khisni, Akhmad.(2020). Legal Protection of Holders of Land Loss Data In The City Land Office of Kendari. JURNAL AKTA: Vol. 7, No. 2, 159-164. Retrieved from http://jurnal.unissula.ac.id/index.php/akta/article/view/7963
} 
between PT. Karyadeka Alam Lestari with farmers from Trisobo Village, Kendal Regency by the Regional Office of the National Land Agency of Central Java Province, is in accordance with the National Land Law?; What are the obstacles faced by the Regional Office of the National Land Agency of Central Java Province in resolving land rights tenure disputes between PT. Karyadeka Alam Lestari with farmers from Trisobo Village, Kendal Regency?; and How to follow up on the settlement of land rights tenure disputes between PT. Karyadeka Alam Lestari with farmers from Trisobo Village, Kendal Regency through Agrarian Reforma?

\section{Research Methods}

This study uses an empirical juridical approach with explanatory analysis research specifications. Primary data of this study were obtained from interviews with Central Java Provincial Office, Kendal District Land Office, PT. Karyadeka Alam Lestari and the head of Trisobo village using the snowball sampling method. The data collection techniques used were library studies and field studies. The data analysis technique used descriptive qualitative.

\section{Results and Discussion}

\subsection{The reasons for the dispute over land rights between PT. Karyadeka Alam Lestari with Trisobo Farmers, Boja District, Kendal Regency}

History has recorded that the order of democratic life in Indonesia has shifted towards an era of openness so that people have had the courage to convey their aspirations about a condition they feel about the existence of injustice in their lives. This is what happened to the people of Trisobo village, Boja sub-district, Kendal district who have lived side by side with PT. Karyadeka Alam Lestari as the manager of a rubber plantation in Trisobo Village, however, has never provided an adequate contribution to the Trisobo Village community in particular and the Kendal community in general. ${ }^{8}$

So that on March 28, 2000 (two years before the end of the HGU period), the village and NGOs filed an objection if the HGU of PT. Karyadeka Alam Lestari was extended, reporting the problem to the local government. Because they believed that the land before 1925 belonged to the people (their ancestors) who had been confiscated by the Dutch to become a garden, therefore the village and NGOs demanded that new rights be granted to residents for the return of the land they occupied and worked on. The residents think that the cultivated land they occupy is inherited from their ancestors, so that it should be returned to the Trisobo Village community after the validity of the Business Use Rights (HGU) since December 31, 2002, regardless of who currently controls and so that PT. ${ }^{9}$

\footnotetext{
${ }^{8}$ Results of Interviews with the Secretary of Trisobo Village, Boja District, Kendal Regency, Suwondo

${ }^{9}$ Putra, Axel Budi., \& Maryanto. (2019). Legal Analysis of the Form Deed of Sale and Purchase Agreements and the Disposal of Land Rights as the Basic Right to Apply Broking Which Has Expired. JURNAL AKTA: Vol. 6, No. 4, 733-740. Retrieved from http://jurnal.unissula.ac.id/index.php/akta/article/view/7624
} 
Then the Kendal Regency Government facilitated the settlement of the dispute by deliberation, including on May 9, 2000 at the Regionala Secretary Area (Sekwilda) Office, May 13, 2000 at Commission A of the Kendal Regency DPRD which was followed up with a field review on May 16, 2000 followed by a discussion of the results of the field survey on May 23, 2000 at Kendal Regency DPRD, but no agreement was reached and NGOs still demanded the return of the land; even after returning from the DPRD, the community destroyed their gardens, tapped rubber sap, burned garden facilities and closed access roads to the gardens. This action resulted in a criminal case;

As a result of the conflict, PT. Karyadeka Alam Lestari which was submitted since 2000 cannot be further processed. These problems still cannot be resolved because each party is still holding on to its own will.

Based on these things, in my opinion, the reasons for the dispute were the social disparities between the Trisobo village farmers and PT. Karyadeka Alam Lestari so that farmers take advantage of the momentum of the end of the HGU of the land to control it on the grounds that the land is inherited from their ancestors.

\subsection{Suitability of Land Rights Dispute Settlement between PT. Karyadeka Alam} Lestari with Farmers in Trisobo Village, Boja District, Kendal Regency By the Regional Office of the National Land Agency of Central Java Province with National Land Law

Based on article 33 paragraph 3 of the 1945 Constitution which reads "the land and water and natural resources contained therein are controlled by the state and used for the greatest prosperity of the people" and article 2 paragraph 2 of the UUPA which reads "the right to control of the state as meant in paragraph 1 in this article authorizes: (a) to regulate and administer the designation, use, supply and maintenance of the earth, water and space; (b) determine and regulate the legal relationships between people and earth, water and space; (c) determine and regulate legal relations between people and legal acts concerning the earth, water and space ", the Head of the Regional Office of the Central Java Province BPN, as a representative of the government agency authorized to implement these provisions, ${ }^{10}$ :

a. To PT. Karyadeka Alam Lestari regarding the application for an extension of HGU Number 01 with an area of $131.10 \mathrm{Ha}$ located in Trisobo village, BPN proposed to PT. Karyadeka Alam Lestari in order to release part of the land for which the right was requested to be given to Trisobo village farmers as an effort to accommodate farmers' requests.

b. To the people of Trisobo village not to force their will to own the land area according to their cultivated land which is considered their ancestral land (illegal cultivation)

The solution steps offered by the BPN Office are based on Government Regulation Number 24 of 1997 Article 30 paragraph (1) letter c and Article 45 paragraph (1) letter

\footnotetext{
${ }^{10}$ Results of Interviews with the Head of the Study and Handling of Land Disputes and Conflicts, Joko Budiyanto, SH, MM, M.Kn
} 
e and PERKABAN Number 3 of 1997 Article 63 paragraph (3) letter b, which according to the aforementioned provisions that the application for an extension of the HGU of PT. Karyadeka Alam Lestari could not be further processed due to a dispute with the farmers in Trisobo Village.

As for the peasants in Trisobo Village, their desire to own their cultivated land will not be fulfilled on the basis that the land is inherited from their ancestors, not supported by strong evidence, even its cultivation is illegal.

With the emergence of this dispute, the Regional Office of the National Land Agency of Central Java Province and the Kendal Regency Land Office, as non-departmental institutions at that time, were under and directly responsible to President Number 10 of 2006 concerning the National Land Agency, obliged to resolve the dispute. This is in line with the "Eleven Agenda for Agrarian Reforma of the National Land Agency", whose fifth agenda is to systematically handle and resolve land cases, problems, disputes and conflicts throughout Indonesia. ${ }^{11}$

\subsection{Barriers Faced by the Regional Office of the National Land Agency of Central Java Province in Resolving Land Rights Disputes Between PT. Karyadeka Alam Lestari with Farmers in Trisobo Village, Boja District, Kendal Regency}

The mediation that was carried out was initiated by the Regional Government and the Regional People's Representative Council of Kendal Regency since early 2000, however the mediation has been carried out many times but has not been able to produce a solution by both parties.

Then this issue was also tried to be mediated by the Regional Office of the Central Java Province Land Agency in mid-2008 with a more focus on providing understanding to each party in their legal position or legal relationship with the object of the dispute. In this case, the Regional Office of the Central Java Province Land Agency as the mediator experienced obstacles in the mediation.

Based on the results of the author's research, these obstacles include how to provide a correct understanding of the law so that each party does not only cling to their respective interests.

3.4. Follow-up to the Settlement of Land Rights Dispute between PT. Karyadeka Alam Lestari with Farmers in Trisobo Village, Boja District, Kendal Regency through Agrarian Reforma

Conflict problems between communities / NGOs and PT. The resolution of Karyadeka Alam Lestari which has been sticking since the beginning of 2000 continues to be

\footnotetext{
${ }^{11}$ Resmiyanti, Titi., Khisni, Akhmad, \& Sulchan, Achmad. (2019). Dispute over Double Certificate on the National Land Agency of Indramayu District. JURNAL AKTA: Vol. 6, No. 4, 703-710. Retrieved from http://jurnal.unissula.ac.id/index.php/akta/article/view/7577
} 
endeavored, facilitated by the Kendal Regional Government, Kendal DPRD and the Regional Office of BPN, Central Java Province, with the following results ${ }^{12}$ :

a. Based on the letter of the Deputy Regent of Kendal dated April 14, 2008, No. 525/90 / Hk addressed to the Governor of Central Java, regarding the Facility Results Report on HGU issues on behalf of PT. Karyadeka Alam Lestari, among others were reported:

1) in principle, an application for an extension of the HGU of PT. Karyadeka Alam Lestari will provide assistance for the development of Trisobo Village

2) PT. Karyadeka Alam Lestari is willing to release part of its land for Trisobo Village

b. Based on the report of the Deputy Regent of Kendal above, the Governor of Central Java in accordance with his letter dated 23 June 2009 No. 593.4 / 12962, in principle the application for HGU PT. Karyadeka Alam Lestari can be considered for approval.

c. The efforts to resolve the conflict over the PT. Karyadeka Alam Lestari through mediation was also facilitated by the Regional Office of the National Land Agency of Central Java Province, including mediation on 21 October 2008, 30 December 2008, 2 February 2009, 12 February 2009 and continued on 1 April 2009 at the Trisobo Village Hall with at attended by the people of Trisobo Village (some of whom are members of the NGO PPNT and NGO FORMAT), the Central Java Provincial Government, the District Government. Kendal, Mupika Boja, District Land Office. Kendal, with the results of the meeting / agreement, among others:

1) The Head of the Regional Office of the National Land Agency for Central Java Province informed that after several meetings with the Trisobo Village Head, local community leaders, NGOs PPNT, FORMAT and PT. Karyadeka Alam Lestari, which is facilitated by the Regional Office of the National Land Agency of Central Java Province, it has been agreed that the area of land given over by PT. Karyadeka Alam Lestari is $\mathbf{1 1 . 5}$ hectares to be used and utilized for the welfare of the Trisobo Village community;

2) At the meeting, the farmers who lived in Trisobo Village could receive land from PT. Karyadeka Alam Lestari;

3) The people of Trisobo Village will not interfere with the process of extending the PT. Karyadeka Alam Lestari and will not disturb PT. Karyadeka Alam Lestari;

4) The National Land Agency will process the application for extension / renewal of the PT. Karyadeka Alam Lestari as priority rights holder and other parties who do not accept are welcome to take legal action.

d. Settlement efforts through the Kendal Regency DPRD, based on the letter of the Kendal Regency DPRD Chairperson addressed to the Kendal Regent dated 27 July 2010 Number 172.04 / 849 / DPRD regarding the Report on the Results of the Work Meeting of Commission A DPRD Kendal Regency, in conjunction with the Report on the results of the Work Meeting of the Kendal Regency DPRD Commission A Number 15 / A / DPRD / VII / 2010 dated 27 July 2010 concerning the Discussion on

\footnotetext{
12 Results of Interviews with the Head of the Dispute Section of the Land Office of Kendal Regency, Wahana, SH, MH
} 
the Extension of the PT. Karyadeka Alam Lestari Trisobo Village, Boja District, Kendal Regency in the recommendation stated that Commission A could understand and assess that the HGU extension on behalf of PT. Karyadeka Alam Lestari, which is located in Trisobo Village, Boja District, is in accordance with the procedures and laws in force.

e. Follow-up Settlement

1) Based on the foregoing, and considering the Letter of the Deputy Regent of Kendal dated April 14, 2008, No. 525/90 / Hk, Central Java Governor's Letter dated 23 June 2009 No. 593.4 / 12962 which principally applies to PT. Karyadeka Alam Lestari can be considered for approval and based on the results of the inspection by the Central Java Province Land Inspection Committee (Panitia B) dated May 5, 2009 No. 540 / Ris.Pan. B / 01 / BH / V / 33/2009, then issued a Decree of the Head of the Regional Office of the National Land Agency for Central Java Province dated June 30, 2009 Number: SK.80-550.2-33-2009, concerning the granting of HGU on behalf of PT. Karyadeka Alam Lestari and based on this decree the Kendal Regency Land Office on July 16, 2009 issued a HGU certificate on behalf of PT. Karyadeka Alam Lestari, namely: HGU No. 2 Trisobo Village covering an area of 51.9054 hectares, HGU No. 3 Desa Kertosari covering an area of 25,0752 hectares, HGU No. 4 Trisobo Village covering an area of 54,2403 hectares, HGU No. 5 Kertosari Village covering an area of 8,3673 hectares and HGU No. 6 Kertosari Village covering an area of 9,0356 hectares;

2) PT. Karyadeka Alam Lestari has handed over 11.5 hectares to Trisobo Village and handed over \pm Rp. 300 million for the construction of the Trisobo village hall.

3) That the 11.5 hectare land has been followed up with the Land Redistribution program for 2011 and a number of 560 freehold certificates have been issued, namely No.318 to No.877 located in Trisobo Village, Boja District, Kendal Regency.

f. Asset Legalization (Asset Reform)

The Agrarian Reforma Program in the Kendal Regency area, in the sense of Redist Plus, is located in Trisobo Village, Boja District with a land history that PT. Karyadeka Alam Lestari domiciled in Jakarta is the holder of Business Use Rights No. 1 Trisobo Village covering an area of $131.1 \mathrm{Ha}$, whose rights have expired on December 31, 2002. As a priority right holder and there is also support from the Regent of Kendal (Letter dated 14-04-2008 Number 525/90 / Hk) PT. Karyadeka Alam Lestari submitted a request for renewal of the HGU. ${ }^{13}$ Further developments from the results of meetings with local community leaders and the Trisobo Village Head with PT. Karyadeka Alam Lestari, it was agreed that $11.5 \mathrm{Ha}$ of the HGU was handed over / released for the welfare of the poor people of Trisobo Village. As for the ex-HGU State land of PT. Karyadeka Alam Lestari was released by the Company

\footnotetext{
${ }^{13}$ Results of Interviews with the Head of Section P3 of the Land Office of Kendal Regency, Chita Satyawati, SH, M.Si.
} 
with a Declaration Letter number 024 / KAL-IMO / S.Per / V / 2009 dated May 15, 2009.

Furthermore, after conducting an inventory of state land tenure in Trisobo Village, Boja Subdistrict, data on the heads of families (KK) who will receive benefits / cultivators of 560 households with a total arable area of 11.5 hectares were obtained. Based on these data, the Kendal Regency Land Office carries out data collection and research on subjects and objects in order to determine the priority scale of cultivators who meet the requirements to be designated as potential recipients of land redistribution as referred to in articles 8 and 9 of Government Regulation Number 224 of 1961.

The stages taken in completing the Land Reforma Object Land Redistribution (TOL) activities are as follows:

1) Determination / Determination of location by the Head of the Regional Office of the National Land Agency of Central Java Province, dated 24 February 2011 Number SK 1465 / 14.33.400 / II / 2011, which was revised on August 10, 2011, Number SK. 4821 / 14-33,400 / VIII / 2011.

2) Counseling / outreach

3) PPL Session (LandReforma Advisory Committee) and Signing of Minutes Number: 01 / BA / VI / 2011 Date: 28-06-2011

4) Proposal for Affirming State Land to Become LandReforma Object (to BPN RI / Central) No. 289 / 33.24 / VII / 2011 Dated. 21-07-2011

5) Decree of the Head of BPN RI No. 92 / Pag / 19/2011 dated 15 November 2011 concerning: Affirmation of Land Directly Controlled by the State as an Object of Land Reforma on Land Located in Kendal Regency, Central Java Province

6) Measurement and Mapping of Land Plots totaling 560 fields

7) Issuance of Property Rights Decree (by the Head of the Kendal District Land Office) No. 420.2.24 / 01 / NEG Date. 07-12-2011

8) Issuance of certificates dated 23-12-2011 totaling 560 fields, namely Property Rights No. 318 s / d No. 877.

g. Reforma Access Development

Access to Reforma built in Trisobo Village, is a portrait of potential activities in the village including Freshwater Fishery Business, Cassava Chips Home Industry, Furniture Making, Various Agricultural Commodities, Iron Pande, Workshop Business, and other types of business.

As for this initial stage, what will be cultivated and developed is the type of cassava chips business, on the grounds that there are many home industries for cassava chips, Trisobo cassava chips have a distinctive taste (crispy, delicious, fantastic), the cultivation of cassava plants is widely developed., the soil structure in Trisobo village is suitable for cultivating cassava plants.

The role of mentoring and capital will greatly help promote the cassava chips business. Assistance is needed to always be able to control quality and quantity, flavor innovation, packing (packaging), marketing, production sustainability (to be 
stable), because currently there is a shortage of cassava raw materials. The roles of related SKPD include the Agriculture, Animal Husbandry, Plantation and Forestry Service, Industry and Trade Service, and other agencies. In order to facilitate and expedite communication relations between communities, groups were formed, which then rejoined into one institution which was incorporated under the Act No. 15 dated April 7, 2012. The container is named Gapoktakum "Domas" (Association of Farmer Groups and Independent Business Activities "Domas"). ${ }^{14}$

Whereas on June 5, 2012, a Mutual Agreement was signed by 4 (four) Parties, namely the Kendal Regency Government, the Kendal Regency Land Office, the Kendal Branch of Bank Jateng, PT. Karyadeka Alam Lestari Semarang.

\section{Closing}

\subsection{Conclution}

The obstacles faced by the Regional Office of the National Land Agency of Central Java Province in resolving PT. Karyadeka Alam Lestari and farmers from Trisobo village, Boja sub-district, Kendal district, are in providing a correct legal understanding of land tenure to the disputing parties.

\subsection{Suggestion}

The follow up actions taken by BPN in resolving land disputes between PT. Karyadeka Alam Lestari with Trisobo farmers is by issuing a decree of the head of BPN RI Number 024 / KAL-IMO / S.Per / V / 2009 concerning the affirmation of land directly controlled by the state as the object of land Reforma on May 15, 2009. Then the head of the Kendal Regency Land Office issued Decree of the head of the Land Office No. 92 / Pag / 19/2011 Date. November 15, 2011 concerning the granting of ownership rights in the context of redistribution of land Reforma objects to 560 families (560 fields) of farmers in Trisobo village, Boja sub-district, Kendal district. The redistribution of land in the village is included in the agrarian Reforma program.

\section{References}

Journals:

[1] Putra, Axel Budi., \& Maryanto. (2019). Legal Analysis of the Form Deed of Sale and Purchase Agreements and the Disposal of Land Rights as the Basic Right to Apply Broking Which Has Expired. JURNAL AKTA: Vol. 6, No. 4, 733-740. Retrieved from http://jurnal.unissula.ac.id/index.php/akta/article/view/7624

[2] Resmiyanti, Titi., Khisni, Akhmad, \& Sulchan, Achmad. (2019). Dispute over Double Certificate on the National Land Agency of Indramayu District. JURNAL

\footnotetext{
${ }^{14}$ Rachmawati, Noor., \& Hanim, Lathifah. (2018). Notary Role in The Establishment of Foreign Investment Limited Company Based on The Act No. 25 Of 2007 on Investment in Semarang. JURNAL AKTA: Vol. 5, No. 4, 965-974. Retrieved from http://jurnal.unissula.ac.id/index.php/akta/article/view/3939
} 
AKTA: Vol. 6, No. 4, 703-710. Retrieved from http://jurnal.unissula.ac.id/index.php/akta/article/view/7577

[3] Alam, Bahrul., \& Khisni, Akhmad. (2020). Legal Protection of Holders of Land Loss Data In The City Land Office of Kendari. JURNAL AKTA Vol. 7, No. 2, 159164. http://jurnal.unissula.ac.id/index.php/akta/article/view/7963

[4] Widyawati, \& Handoko, Widhi. (2018). The Notary Role / PPAT in Improving Legal Awareness Society to Perform Registration Rights to Land Based on Government Regulation No. 24 of 1997 on Land Registration. JURNAL AKTA: Vol. 5, No. 4, 975-980. Retrieved from http://jurnal.unissula.ac.id/index.php/akta/article/view/4127

[5] Harjanto, Fery., \& Gunarto. (2018). Effects Of Creation Deed of Sale and Purchase of Land Which Does Not Match Procedure of Making Land Deeds. JURNAL AKTA: Vol. 5, No. 4, 857-864. Retrieved from http://jurnal.unissula.ac.id/index.php/akta/article/view/3718

[6] Rachmawati, Noor., \& Hanim, Lathifah. (2018). Notary Role in The Establishment of Foreign Investment Limited Company Based on The Act No. 25 Of 2007 on Investment in Semarang. JURNAL AKTA: Vol. 5, No. 4, 965-974. Retrieved from http://jurnal.unissula.ac.id/index.php/akta/article/view/3939

Books:

[1] Harsono, Boedi. (2008). Sejarah Pembentukan Undang-Undang Pokok Agraria, Isi dan Pelaksanaannya Jakarta: Djambat

[2] The National Land Agency of the Republic of Indonesia, Agrarian Reforma, Mandate Political, Constitutional and Legal in the Context of Creating "Land for Justice and People's Welfare", 20 May 2007

Regulations:

[1] MPR Decree No. IX / MPR / 2001 concerning Agrarian Reforma and Management of Natural Resources;

[2] Act No. 5 Of 1960 concerning Basic Agrarian Principles (State Gazette Of 1960 Number 104);

[3] Act No. 51 Prp of 1960 concerning the Prohibition of Use of Land without the rightful permit or proxy;

[4] Act No. 56 of 1960 concerning Stipulation of Agricultural Land Areas (State Gazette of 1960 Number 174);

[5] Government Regulation Number 224 of 1961 concerning Implementation of Land Distribution and Compensation (State Gazette of 1961 Number 208);

[6] Government Regulation Number 41 Of 1964 concerning Amendment and Supplement to Government Regulation Number 224 Of 1961 concerning Implementation of Land Distribution and Compensation (State Gazette Of 1964 Number 112);

[7] Government Regulation Number 24 of 1997 concerning Land Registration (State Gazette of 1997 Number 59); 
[8] Government Regulation Number 40 of 1996 concerning Business Use Rights, Building Use Rights and Land Use Rights;

[9] Presidential Regulation of the Republic of Indonesia Number 17 of 2015 concerning the Ministry of Agrarian Affairs and Spatial Planning;

[10] Presidential Regulation of the Republic of Indonesia Number 20 of 2015 concerning the National Land Agency;

[11] Presidential Decree No. 55/1980 on the Organization and Administration of LandReforma Implementation;

[12] Presidential Decree Number 34 of 2003 concerning National Policy in the Land Sector;

[13] Decree of the Minister of Home Affairs Number 38 of 1981 concerning Implementation of Presidential Decree Number 55 of 1980 concerning Details of Duties and Work Procedures for LandReforma Implementation;

[14] Decree of the State Minister for Agrarian Affairs / Head of the National Land Agency Number 11 of 1997 concerning Control of Land Reforma objects;

[15] Regulation of the Head of the National Land Agency of the Republic of Indonesia Number 1 of 2014 concerning the Organization and Administration of the National Land Agency of the Republic of Indonesia;

[16] Decree of the Head of the National Land Agency Number 25 of 2002 concerning Guidelines for Implementing Applications for Confirmation of State Land to be the Object of Land Control / LandReforma Regulations;

[17] Decree of the Head of the National Land Agency of the Republic of Indonesia Number 34 of 2007 concerning Technical Guidelines for Handling and Solving Land Problems.

Interview:

[1] Results of Interviews with the Secretary of Trisobo Village, Boja District, Kendal Regency, Suwondo

[2] Results of Interviews with the Head of the Study and Handling of Land Disputes and Conflicts, Joko Budiyanto, SH, MM, M.Kn

[3] Results of Interviews with the Head of the Dispute Section of the Land Office of Kendal Regency, Wahana, $\mathrm{SH}, \mathrm{MH}$

[4] Results of Interviews with the Head of Section P3 of the Land Office of Kendal Regency, Chita Satyawati, SH, M.Si. 